\title{
WATER RESOURCES MANAGEMENT IN LIBYA: CHALLENGES AND FUTURE PROSPECTS
}

\author{
Jauda R. Jouda Hamad ${ }^{1,2}$, Marlia M. Hanafiah ${ }^{1 *}$, Wan Zuhairi W. Yaakob ${ }^{1}$
}

${ }^{1}$ School of Environmental and Natural Resource Sciences, Faculty of Science and Technology, Universiti Kebangsaan Malaysia, 43600 Bangi, Selangor, Malaysia

${ }^{2}$ Marine Science Department, Faculty of Natural Resource and Environmental Science, Omar Al-Mukhtar University, Libya

*Corresponding Author E-mail: mhmarlia@ukm.edu.my; Tel.: 03-89215865; fax: +603-89253357

This is an open access article distributed under the Creative Commons Attribution License, which permits unrestricted use, distribution, and reproduction in any medium, provided the original work is properly cited

\section{ARTICLE DETAILS}

Article history:

Received 12 September 2017

Accepted 19 October 2017

Available online 30 October 2017

\section{Keywords:}

Water shortage; Water availability; Sustainable water resources management; Human health:Libva

\begin{abstract}
Water shortage or scarcity is becoming a major concern for many nations across the world. The situation is worsened by rapid urbanization and population growth in developing countries, thus increase competition for water used for irrigated agriculture. Various efforts have been made by the authorities in the developing countries to provide sufficient water and improve the quality of water resources. Yet, there are still many developing countries facing shortages of water for domestic and agricultural purposes, especially during the dry months of the year. Libya is one of the Northern African countries that have been experiencing water shortages especially in urban areas. This paper aims to identify the current situation and constraints of water resources management in Libya. The latter part is devoted to the solutions and recommendations at individual, community, state and government levels that can help solving the water problems in Libya. A number of previous studies on the water resources management and challenges perceived by both developed and developing countries were critically reviewed. It was found that water scarcity in developing countries is expected to be worsen as their population are expected to increase gradually year by year and it can be summarized from the reviewed previous studies that lack of government planning, industrial and human wastes along with government intervention and mismanaging water resources are some of the critical constraints towards achieving sustainable management in most of the countries including Libya. Potential solutions such as improving supply demand and good quality management of water resources must be taken into consideration. In addition, active participation from the local residents by enhancing awareness amongst them would be one of the supportive strategies to minimize the constraints. Sustainable economic and environmental management together with efficient use of water is required to conserve our clean water supply.
\end{abstract}

\section{INTRODUCTION}

Water is vital for sustaining all existence life forms and access to clean and safe drinking water is an important for human need [1]. Developing cities are increasingly facing critical water plight in terms of imbalance between supply and demand [2]. Water issues of the world are neither identical, nor fixed or consistent over time. They often fluctuate very significantly from one location to another, even within a single nation, from one season to another, and also from one year to another. Solutions to water problems depend not only on water availability, but also on several other factors among processes through water supply management [3]. In addition, the water is in movement, or consistent as it is in lakes, it fixedly contains inapposite materials, some due to natural causes but others due to human activities. All these, plus natural differences in water availability, make its rationalistic planning and management a very complex and difficult task under the best of circumstances [4]. The current state of water institutional, infrastructure and water management policies in Libya permit the recognitions and evaluation of a range of options for improving water use capacity in agriculture and the potential role of water pricing in accomplishing sustainability of water sources [5]. The condition of water supply has turned into more problematic with quickly increasing population and minimum rainfall. Consequently, soon after the discovery of fresh groundwater in the deserts of southern Libya, the local authority has made massive efforts to address its water shortfall problems, fundamentally through the enforcement of The Great Manmade River Project to sustain its economy, however, it does not solve the water scarcity in Libya [6].

\section{WATER RESOURCES AND AVAILABILITY}

Water resource and availability play a vital role in both the environment and human life. Eight countries have reviewed in terms of water resources in each country accordingly on both climate change and geographical location. The data presented in Table 1 shows the difference between each country with aim to compare the average of water availability in these countries.

Table 1: Water resources and availability in eight selected countries.

\begin{tabular}{|c|c|c|c|c|c|}
\hline Country & $\begin{array}{l}\text { Ground } \\
\text { water }\end{array}$ & Surface water & $\begin{array}{c}\text { Average } \\
\text { rainfall }\end{array}$ & Author/Year & Remarks \\
\hline Nigeria & $\begin{array}{l}52 \\
\text { billion } \\
\mathrm{m}^{3 / \mathrm{yr}}\end{array}$ & $\begin{array}{l}267 \\
\text { billion } \\
\mathrm{m}^{3} / \mathrm{yr}\end{array}$ & $\begin{array}{l}250 \\
\mathrm{~mm} / \mathrm{yr}\end{array}$ & $\begin{array}{l}\text { Nwankwoala } \\
\text { (2014) }\end{array}$ & $\begin{array}{l}\text { Accessible of water supply } \\
\text { and sanitation in Nigeria is } \\
\text { hampered by geographical, } \\
\text { socio-economic and } \\
\text { institutional factors. and } \\
\text { Water stress. }\end{array}$ \\
\hline India & $\begin{array}{l}432 \\
\mathrm{~km}^{3} / \mathrm{yr}\end{array}$ & $\begin{array}{l}690 \\
\mathrm{~km}^{3} / \mathrm{yr}\end{array}$ & $\begin{array}{l}342.43 \\
\mathrm{~km}^{3} / \mathrm{yr}\end{array}$ & $\begin{array}{l}\text { Bhattacharyya } \\
\text { et al. (2015) }\end{array}$ & $\begin{array}{l}\text { Increasing rate of population } \\
\text { ya growth and there is not } \\
\text { balance between water } \\
\text { resources and water needed. } \\
\text { Water stress. }\end{array}$ \\
\hline Finland & $\begin{array}{l}250 \\
\mathrm{~m}^{3 / \text { day }}\end{array}$ & $\begin{array}{l}10 \% \text { of the } \\
\text { country's } \\
\text { land is } \\
\text { covered by } \\
\text { water }\end{array}$ & $-5 \%$ and $+10 \%$ & $\begin{array}{l}\text { \% Arola } \\
\text { (2015) }\end{array}$ & $\begin{array}{l}\text { The quantitative and } \\
\text { chemical status of the } \\
\text { groundwater is good. } \\
\text { Changes in yearly runoff are } \\
\text { depending on the catchment } \\
\text { area. } \\
\text { No water stresses. }\end{array}$ \\
\hline Sudan & $\begin{array}{l}260 \\
\text { billion } \\
\mathrm{m}^{3 /} \mathrm{yr}\end{array}$ & $\begin{array}{l}84 \\
\text { billion } \\
\mathrm{m}^{3 /} \mathrm{yr}\end{array}$ & $\begin{array}{l}1600 \\
\mathrm{~mm} / \mathrm{yr}\end{array}$ & $\begin{array}{l}\text { Omer } \\
(2010)\end{array}$ & $\begin{array}{l}\text { White Nile river system is } \\
\text { affected by lack of awareness } \\
\text { and legislation. Water stress. }\end{array}$ \\
\hline Ireland & $\begin{array}{l}69,000 \\
\mathrm{~km}^{2} \mathrm{yr}\end{array}$ & $\begin{array}{l}955 \\
\mathrm{~km}^{2} / \mathrm{yr}\end{array}$ & $\begin{array}{l}750-1,250 \\
\mathrm{~mm} / \mathrm{yr}\end{array}$ & $\begin{array}{l}\text { Zhao } \\
\text { and } \\
\text { Crosbie } \\
(2012)\end{array}$ & $\begin{array}{l}25 \% \text { of public drinking water } \\
\text { is derived from groundwater. } \\
\text { Richest country in the world } \\
\text { in terms of water availability. } \\
\text { No water stresses. }\end{array}$ \\
\hline China & $\begin{array}{l}821.8 \\
\text { billion } \\
\mathrm{m}^{3} / \mathrm{yr}\end{array}$ & $\begin{array}{l}830 \\
\text { billion } \\
\mathrm{m}^{3} / \mathrm{yr}\end{array}$ & $\begin{array}{l}585.55 \\
\mathrm{~mm} / \mathrm{yr}\end{array}$ & $\begin{array}{l}\text { Sun et al. } \\
\text { (2017) } \\
\text { Piao et al. } \\
(2010)\end{array}$ & $\begin{array}{l}\text { Among all } 669 \text { cities in } \\
\text { China, } 440 \text { cities have a lack } \\
\text { of water, while } 110 \text { have } \\
\text { severe water shortages. } \\
\text { Groundwwater provides for } \\
\text { about } 70 \% \text { of the drinking } \\
\text { water in the arid north and } \\
\text { northwest China. } \\
\text { Each year, } 190 \text { million people } \\
\text { become ill due to polluted } \\
\text { water from industrial and } \\
\text { agricultural activities. }\end{array}$ \\
\hline Australia & $\begin{array}{l}25.78 \\
\text { a gigalitres } \\
\text { (GL) }\end{array}$ & $\begin{array}{l}23000 \\
\text { gigalitre } \\
(\mathrm{GL})\end{array}$ & $\begin{array}{l}387.18 \\
\text { gigalitres } \\
\text { (GL) }\end{array}$ & $\begin{array}{l}\text { Chartres } \\
\text { And Williams } \\
\text { (2006); c } \\
\text { Iftekhar } \\
\text { and Fogarty gc } \\
\text { (2017) }\end{array}$ & $\begin{array}{l}\text { Water resources are extremely } \\
\text { changing and reflecting with } \\
\text { climate change seasonally. } \\
\text { Australia's water resources are } \\
\text { good in surplus of this per capita } \\
\text { definition of water shortages. } \\
\text { No water stresses. }\end{array}$ \\
\hline Libya & $\mathrm{m}^{3 / y \mathrm{r}}$ & $\begin{array}{l}170 \quad 200- \\
\text { Million } \\
\mathrm{m}^{3 / y r}\end{array}$ & $-300 \mathrm{~mm} / \mathrm{yr}$ & $\begin{array}{l}\text { Abdudayem } \\
\text { And } \\
\text { Scott (2014) }\end{array}$ & $\begin{array}{l}\text { Scarcity of water in Libya is } \\
\text { exacerbated by a growing } \\
\text { population and its dominant } \\
\text { arid geography and desert } \\
\text { climate. Groundwater } \\
\text { supplies almost } 95 \% \text { of } \\
\text { Libya needs. } \\
\text { Water stress. }\end{array}$ \\
\hline
\end{tabular}


A study on water resources in Nigeria and found groundwater resources from boreholes and hand dug wells have become the greater important sources of public and private water in towns and rural areas and also mentioned that expeditious growth in population, civilization, industrialization and competitiveness for economic development [7]. Water resource has become impotent for depletion and degradation and there is an imbalance between demand and availability of water resources. In contrast, carried out a study in India and reported that India's annual probable core of groundwater renew from rainfall is around $342.43 \mathrm{~km} 3$ [8]. In consequences, the population of India is predicted to be 1,333 million and 1,581 million in high growth of 2025 and 2050, respectively. A research found that Sudan is affected by lack of awareness and legislation of the country as well as unequal distribution among the cities, and the variance between water supply and demand is growing with time due to the rapid population growth and aridity [9].

In comparison, a research investigated the current situation of water resource and its management in Ireland [10]. They observed that Ireland is the richest country in the world in terms of water availability. The great majority of drinking water in Ireland is extracted from surface water $(81.9 \%)$ and limited fraction coming from groundwater $10.3 \%$ and springs $7.8 \%$. A researcher also stated in their research that local authorities are in charge of providing water to most of the households and businesses in the country [10]. A study by identified that the groundwater resource in Finland is $250 \mathrm{~m} 3$ per day while the annual rainfall is ranging from $-5 \%$ and $+10 \%$ depends on the catchment area [11]. An attempt was made in China to evaluate the main water resources and considered large with rating sixth in the world per capita representing only $25 \%$ of the world average [12]. Furthermore, the allocation of water resources is spatially and seasonally explicit. Northern and southern part of China holds only $18 \%$ of the total water in spite of having $65 \%$ of the total arable land. By contrast, the south receives water from summer rainfalls, which is often wasted through flooding according to the findings found that North of China faces severe water scarcity. In a study, they have estimated the water recourse in Australia and delineated that the country's water resources are extremely changing and reflecting with climate change seasonally [13]. Therefore, Australia's water resources are good in quantities and qualities and out of the water stress ranked in the world.

In comparison, the main water sources in Libya come from four sources which are groundwater supplies almost 95\% of Libya's needs; surface water only with $2 \%$ comprising rainwater and dam constructions; desalinated from sea water provides $2 \%$ and wastewater recycling $1 \%$ (Figure 1). A research divided the major sources of groundwater in Libya into five water basins namely Jabal al-Akhdar, Kufra as -Sarir, Jefara plain region, Nafusah Al-Hamada and Murzek [5]. Groundwater in the country can be grouped into renewable resources, mainly found in superficial aquifers, and the non-renewable resources (fossil water) come up against in deep aquifers. Groundwater reservoir characteristics are presented in Table 2. They also identified the situation of water shortage in Libya and they considered it worse due to several reasons such as growing population, its predominant arid geography and desertification under a changing climate. An increasing dependence on oil earnings has seen agriculture reduce to only $2 \%$ by 2007 , and facing remarkable challenges with domestic food supplies that unable to meet demand and cultivation limited by a lack of arable land and water supply [14]. The current restricted water resources will get even more and more limited. This morerequired water later on might come at a high budgetary, conservation and environmental costs.

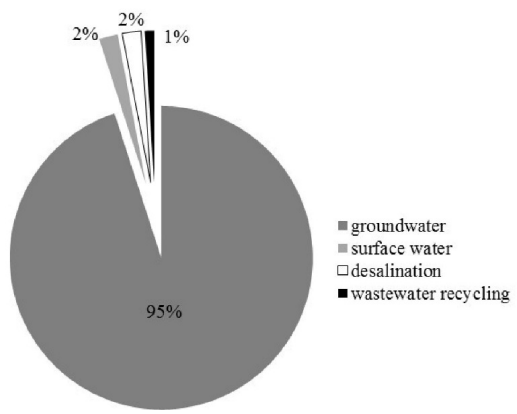

Figure 1: Percentages of available water in Libya

Table 2: Groundwater reservoirs characteristics

\begin{tabular}{|c|c|c|c|c|}
\hline Basin & $\begin{array}{l}\text { Area } \\
(\mathrm{km})^{2}\end{array}$ & $\begin{array}{l}\text { Renewable } \\
10^{6} \mathrm{~m}^{3}\end{array}$ & $\begin{array}{l}\text { Non-renewable } \\
10^{6} \mathrm{~m}^{3}\end{array}$ & $\begin{array}{l}\text { Total } \\
\text { dissolved } \\
\text { Solids, } \mathrm{mg} / 1\end{array}$ \\
\hline Jabal al-Akhdar & 145,000 & 200 & 50 & $1.000-5.000$ \\
\hline Kufra/as-Sarir & 700,000 & - & 1.800 & $200-1.500$ \\
\hline Jefara Plain Region & 18,000 & 200 & 50 & $1.000-5.000$ \\
\hline Nafusah Al-Hamada & 215,000 & 250 & 150 & $1.000-5.000$ \\
\hline Murzek & 350,000 & - & 1.800 & $200-1.500$ \\
\hline
\end{tabular}

\section{CURRENT AND FUTURE WATER CONSUMPTION IN LIBYA}

Estimation was done in 2008 for future consumption in Libya including agricultural, domestic and industrial uses during 2006 to 2020. The future evaluation of water utilization for all potential purposes specified the total water consumption rising from 6,293.89 million m3 in 2006 to 12,473.20 million $\mathrm{m} 3$ in 2020 with an average of compound annual rate of $4.97 \%$ [15]. In 2020, it is expected that the increase would be $98 \%$ of the water consumption in 2006. Table 3 shows some remarkable variation for water demands in different usage and purposes in Libya due to unsuitable climatic and soil conditions.

Table 3: Water demands by different uses in Libya, 2006-2020 forecasts.

\begin{tabular}{|lllll|}
\hline Year & \multicolumn{4}{l}{ Water Demand (million cubic meter) } \\
\hline & Agricultural Use & Domestic Use & Industrial Use & Total Demand \\
$\mathbf{2 0 0 6}$ & $\mathbf{5 , 2 0 4 . 4 3}$ & $\mathbf{8 9 5 . 7 5}$ & $\mathbf{1 9 3 . 7 1}$ & $\mathbf{6 , 2 9 3 . 8 9}$ \\
2007 & $5,384.29$ & 958.96 & 202.30 & $6,545.55$ \\
2008 & $5,601.55$ & $1,022.69$ & 210.70 & $6,834.94$ \\
2009 & $5,854.41$ & $1,084.98$ & 218.69 & $7,158.08$ \\
$\mathbf{2 0 1 0}$ & $\mathbf{6 , 1 7 1 . 3 9}$ & $\mathbf{1 , 1 4 7 . 6 9}$ & $\mathbf{2 2 7 . 2 4}$ & $7,546.32$ \\
2011 & $6,194.89$ & $1,204.19$ & 233.08 & $7,632.16$ \\
2012 & $6,803.48$ & $1,275.93$ & 241.08 & $8,320.49$ \\
2013 & $7,172.95$ & $1,342.17$ & 247.79 & $8,762.91$ \\
2014 & $7,564.41$ & $1,410.49$ & 254.07 & $9,228.97$ \\
\hline \multicolumn{5}{r}{} \\
\hline $\mathbf{2 0 1 5}$ & $\mathbf{7 , 9 7 5 . 7 7}$ & $\mathbf{1 , 4 9 4 . 9 2}$ & $\mathbf{2 5 9 . 8 5}$ & $\mathbf{9 , 7 3 0 . 5 4}$ \\
$\mathbf{2 0 1 6}$ & $8,405.78$ & $1,555.31$ & 265.12 & $10,226.21$ \\
$\mathbf{2 0 1 7}$ & $8,853.87$ & $1,631.83$ & 269.82 & $10,755.52$ \\
$\mathbf{2 0 1 8}$ & $9,320.22$ & $1,711.56$ & 273.93 & $11,305.71$ \\
$\mathbf{2 0 1 9}$ & $9,805.61$ & $1,794.76$ & 277.41 & $11,877.78$ \\
$\mathbf{2 0 2 0}$ & $\mathbf{1 0 , 3 1 1 . 3 0}$ & $\mathbf{1 , 8 8 1 . 6 6}$ & $\mathbf{2 8 0 . 2 4}$ & $\mathbf{1 2 , 4 7 3 . 2 0}$ \\
& & & & \\
\hline
\end{tabular}

Source: Lawgali (2008)

\section{WATER POLLUTION}

Water pollution is a paramount concern existing in both developed and developing nation's drinking water. It has been suggested that it is the leading worldwide cause of death and disease accounts for the death of more than 14,000 people daily [16]. Physico-chemical and bacteriological analyses conducted in Ilorin, Nigeria investigated the quality of drinking water and found that total hardness ranged between $51-175.5 \mathrm{mg} / \mathrm{l}$ while conductivity was between $65-318 \mu$ s. Ca and $\mathrm{Mg}+2$ varied between 33.7 $102.3 \mathrm{mg} / \mathrm{l}$ and $3.5-57.1 \mathrm{mg} / \mathrm{l}$ respectively. E. coli and coliforms were found high counts and concluded that the main sources of pollution were specified to be the direct runoff from the industries and refuse dumps within the Asa Dam industrial estate [17]. Another study carried out on water pollution in Aligarh city, India examined several trace elements $(\mathrm{Ni}$, $\mathrm{Zn}, \mathrm{Fe}, \mathrm{Pb}, \mathrm{Cd}, \mathrm{Co}, \mathrm{Cu}$ and $\mathrm{Mn}$ ), reported that excessive ratio of some elements in the drinking water and poor health of residents are existing cause of spreading of diseases in Aligarh and the water considered polluted [18]. In comparison, groundwater is of a good quality in the northsouth aquifer, this is because the aquifer lies close to the sources of natural recharge from the Sirir Basin Aquifer. In the area of north Alwahat near the oil settlement where groundwater over-abstraction has been most severe saline intrusion has occurred. In the Jakera area, north of Alwahat, the water quality is too poor even to grow salt-tolerant crops such as dates. A study conducted in Al Wahat area (Libya) mentioned that the quality of water drawn from wells is deteriorating with time. 34 water samples collected from domestic and agricultural water wells were analyzed to identify the water type and ions concentration and found that significant increase of dissolved salts, especially nitrates [19]. Therefore, irrigation wells revealed that suffering from nitrate contamination caused an increase of the chance of nitrate pollution.

Elsewhere, evaluated the quality of drinking water in Finland [20]. Data were collected from different size waterworks in the whole country included wells, water cooperatives, and small, medium-sized, large waterworks and consumer's tap. A study concluded that drinking water in Finland matched with high quality and out of any substances [20]. Similarly, a study conducted in Sudan stated that resigning salinity of drinking water was observed together with human incompatibility and increase in livestock mortalities also in high concentrations and a toxic health endangerment were assessed for lead and barium [21]. A study investigated water quality in Ireland and their results showed that concentration of arsenic in groundwater is below $7.5 \mu \mathrm{g}$ [22]. They indicated that several areas with elevated arsenic concentrations in groundwater were treated using technologies. In China, evaluated the quality of drinking water and they found out that heavy metal releases of $\mathrm{Mn}, \mathrm{Ni}, \mathrm{Cu}, \mathrm{Pb}, \mathrm{Cr}$ and as found in high ratio in both groundwater and residential wells [23]. Investigation of water quality has been reported in Australia to examine the concentration of eight heavy metals in surface and groundwater and found that metal concentrations (except $\mathrm{Cu}, \mathrm{Mn}, \mathrm{Ni}$, and $\mathrm{Zn}$ ) in both surface and groundwater were above the drinking water quality guidelines [24]. 
In Nigeria, approximately $60-70 \%$ of the population is currently without either water or wastewater services, leakage rate is around $50 \%$, illegal connections are rising and urban community does not have a proper sewerage system [26]. Water supply sector in India is facing challenges to ensure supply for potable water to half of people who are currently living without access to sustainable safe drinking water. Therefore, major constraints facing by many developing countries include increasing scarcity of water, low pricing, high subsidy, high cost of recovery, high non-revenue water due to poor maintenance [2]. The quality of drinking water is affected by many factors including the source of water supply, water treatment techniques (sedimentation, filtration, disinfection) and distribution mode. In addition, funding from the high authority in charge of water supply is provided and high level of awareness on sustainability of water [20]. In Sudan, several problems related to water supply include monetary issue, imbalance between water resource and demand due to poor techniques and climate variability as well as lack of awareness among residents and local community [9].

While extensive survey in Finland for drinking water distributed by the waterworks has usually in high quality in terms of hygiene and sanitation aspects. A conclusion drawn indicated that Ireland's public and private sectors are participating in water supply management [27]. They also stated that training and awareness programs are conducted among the society to educate them for using their water duly. In China, observed that the key to success in water management depends on how field regulators approach polluting problems [28].

However, the lack of technical support and training was seriously affected the water supply management. Therefore, as a technical constraint in Libya, the study carried out that one of the existing problems in water supply was the deterioration of desalination station in each coastal city across the county, cost barrier, lack of regular maintenance, poor technical and the low awareness of its integration [14]. Libya faced many problems mainly related to managerial and technical failures [14]. Moreover, another study in Libya, found that government of Libya was not funded the water supply sectors equally to support the water needs [19]. Furthermore, water distribution system in Libya is ancient and facing barriers of leakages and also abstraction equipment as well as the size of the network pipeline and reported that only limited repairs are being done to critical infrastructure in each city of Libya. Since the Libyan's revolution in 2011, many negative impacts happened in the country which cause troubles to the people lead to the damage of public utilities such as water pipes system and electricity power generation. Therefore, the scarcity of freshwater resources proportionally increases the intensity of potential for political conflicts over water within the Libyan cities.

\section{THE WAY FORWARD TOWARDS SUSTAINABLE WATER RESOURCE MANAGEMENT}

Water is becoming a scarce and valuable resource as population and consumption rise. Water consumption is increasing gradually day by day and. Human factors which influence the availability of water, including population, dams and daily usage of water by both individuals and government levels contribute to water crisis. Evaluation of these factors, as well as technology and action to support healthy water supplies, is become crucial, particularly in arid regions like Libya. However, in order to help the country of Libya to be sustained in using their water resource management, the following solutions are highlighted:

1. Innovative policies and new technologies that reduce wastewater are helping countries across the Middle East and North Africa to deal with chronic water shortages.

2. Education to improve lifestyle and reduce water consumption is needed. People need to be motivated to change their behaviour in consuming water.

3. Irrigation and agriculture practices need to be improved. Improving this issue will help in filling the gaps between the water supply and demand since large percentage of the world's freshwater is used for agriculture.

4. International framework and cooperation need to be established. Although this is very hard to be achieved in many countries but making international accords will be beneficial in dealing water scarcity issues.

5. Recycling wastewater is required. This can also be another solution to help with the water shortage. This is currently one of the ways to save the consumption of water and avoid scarcity where some countries like Singapore are trying to recycle to cut water imports and become more self-sufficient.
Water shortage or scarcity is becoming a major concern for many nations across the world and Libya without exception. The situation is worsened by rapid urbanization and population growth in developing countries. This study was aimed at identifying the current situation of water resources management and the constraints currently facing by Libya. As conclusion, it can be said that water shortage in Libya is due to some natural causes and human activities. Climate change is the main reason of water scarcity due to its geographical location. Lack of financial support from high authorities is seen as another reason leading to water shortage and scarcity. Currently, Libya is considered poor in managing its water supply management and resources because of the instability of political condition in the country. These issues have made the situation of water management resources unsustainable. Perhaps, one of the critical problems that hinder sustainable water management development in Libya is the lack of renewable water resources. Therefore, it is suggested that installing desalination according to Libya's geographical location which is in the Mediterranean Sea could help to elevate water shortage issue. There is indeed an urgent need for Libya to sustain its water resource management and this could be possible if the above-mentioned solutions be taken into serious consideration by the Libyan government.

\section{ACKNOWLEDGEMENT}

Marlia Mohd Hanafiah was financed by the UKM research grants (FRGS/2/2013/STWN01/UKM03/1) and (TD-2014-012). Special thanks also extended to the financial support provided by the Ministry of Higher Education in Libya.

\section{REFERENCES}

[1] Iyer, V., Choudhury, N., Azhar, G.S., and Somvanshi, B. 2014. Drinking Water Quality Surveillance in a Vulnerable Urban Ward of Ahmedabad. Health, 6, 1165-.12-25.

[2] Raj, K. 2013. Sustainable Urban Habitats and Urban Water Supply: Accounting for Unaccounted for Water in Bangalore City, India. Current Urban Studies, 1, 156-165.

[3] Biswas, A. K. 2004. Integrated water resources management: a reassessment: a water forum contribution. Water international, 29, 248-256.

[4] Biswas, A. K. 2008. Integrated water resources management: Is it working? International Journal of Water Resources Development, 24, 5-22.

[5] Abdudayem, A., and Scott, A. H. 2014. Water infrastructure in Libya and the water situation in agriculture in the Jefara region of Libya. African Journal of Economic and Sustainable Development, 3, 33-64.

[6] Wheida, E., and Verhoeven, R. 2007. An alternative solution of the water shortage problem in Libya. Water Resources Management, 21, 961-982.

[7] Nwankwoala, H. O. 2014. Problems and options of integrated water resources management in Nigeria: administrative constraints and policy strategies. International Letters of Natural Sciences, 9, 12-25.

[8] Bhattacharyya, A., Reddy, J. S., Ghosh, M., and Naika, R. H. 2015. Water Resources in India: Its Demand, Degradation and Management. International Journal of Scientific and Research Publications, 5 (12), 1-11.

[9] Omer, A. M. 2010. Water resources management and sustainable development in Sudan. International Journal of Water Resources and Environmental Engineering, 2, 190-207.

[10] Zhao, Y., and Crosbie, D. 2012. Water pricing in Ireland: a technoeconomic and political assessment. International Journal of Environmental Studies, 69, 427-442.

[11] Arola, T. 2015. Groundwater as an energy resource in Finland. Academic Dissertation. Department of Geosciences and Geography, University of Helsinki, Finland.

[12] Piao, S., Ciais, P., Huang, Y., Shen, Z., Peng, S., Li, J., Zhou, L., Liu, H., Ma, Y., and Ding, Y. 2010. The impacts of climate change on water resources and agriculture in China. Nature, 467, 43-51.

[13] Chartres, C., and Williams, J. 2006. Can Australia overcome its water scarcity problems?Journal of Developments in Sustainable Agriculture, 1, 17-24.

[14] Wheida, E., and Verhoeven, R. 2004. Desalination as a water supply 
Runge, C., and Ariki, J. 2017. High concentrations of lead and barium in hair of the rural population caused by water pollution in the Thar Jath oilfields

[15] Lawgali, F. F. 2008. Forecasting water demand for agricultural, industrial and domestic use in Libya. International Review of Business Research Papers, 4, 231-248.

[16] Aboyeji, O. 0. 2013. Freshwater pollution in some Nigerian local communities, causes, consequences and probable solutions. Academic Journal of Interdisciplinary Studies, 2, (13) 111- 117.

[17] Adekunle, A. S., and Eniola, I. 2008. Impact of industrial effluents on quality of segment of Asa River within an industrial estate in Ilorin, Nigeria. New York Science Journal, 1, 17-21.

[18] Taqveem, Ali, K. 2011. Trace elements in the drinking water and their possible health effects in Aligarh City, India. Journal of Water Resource and Protection, 3 (7), 522-530.

[19] Alamin, S., Fewkes, A., and Goodhew, S. 2010. Investigating the sustainability of water management in Alwahat, Libya. WIT Transactions on Ecology and the Environment, 129, 607-617.

[20] Mäkinen, R. 2008. Drinking water quality and network materials in Finland: summary report. Publications of Finnish Institute of Drinking Water, 5.

[21] Pragst, F., Stieglitz, K., Runge, H., Runow, K.-D., Quig, D., Osborne, R., in South Sudan. Forensic Science International, 274, 99-106.

[22] Mcgrory, E. R., Brown, C., Bargary, N., Williams, N. H., Mannix, A., Zhang, C., Henry, T., Daly, E., Nicholas, S., and Petrunic, B. M. 2017. Arsenic contamination of drinking water in Ireland: A spatial analysis of occurrence and potential risk. Science of the Total Environment, 579, 1863-1875.

[23] Sun, Y., Liu, N., Shang, J., and Zhang, J. 2017. Sustainable utilization of water resources in China: A system dynamics model. Journal of Cleaner Production, 142, 613-625.

[24] Saha, N., Rahman, M. S., Ahmed, M. B., Zhou, J. L., Ngo, H. H., and Guo, W. 2017. Industrial metal pollution in water and probabilistic assessment of human health risk. Journal of Environmental Management, 185, 70-78.

[25] Hall, D. 2006. Water and electricity in Nigeria. PSIRU Reports.

[26] Kelly-Quinn, M., Blacklocke, S., Bruen, M., Earle, R., O'neill, E., O'sullivan, J., and Purcell, P. 2014. Dublin Ireland: a city addressing challenging water supply, management, and governance issues. Ecology and Society, 19, (4),10-13.

[27] Yu, X., Geng, Y., Heck, P., and Xue, B. 2015. A review of China's rural water management. Sustainability, 7, 5773-5792.

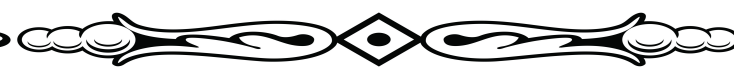

